\section{Californians hash out guide for spending stem-cell billions}

\section{Jonathan Knight, Irvine}

The authors of California's plan to spend $\$ 3$ billion on human embryonic stem-cell research met this week to work out how the money should be distributed. The group has always said it plans to create a miniature version of the National Institutes of Health; the meeting gave it a taste of how hard that is likely to be.

On 6 and 7 December, experts on grant-making, facilities management, research ethics and intellectual property met at a conference hosted by the National Academy of Sciences in Irvine, California. They produced a lengthy list of details to be hammered out before any grants can be awarded.

The grant money will come from Proposition 71, a measure that was designed to fill a funding gap left by federal limitations on stem-cell research. The initiative, which passed on 2 November, establishes the California Institute for Regenerative Medicine, but leaves details of how the institute will be run to committees that have yet to be formed. State officials must nominate members of the supervisory committee by 13 December - 9 out of 29 had been chosen when Nature went to press - and three advisory committees must be appointed by mid-January.

Some decisions will need to be made quickly. Denis Baylor, senior scientific officer at the Howard Hughes Medical Institute, wanted to know whether grants would be awarded on the basis of the merits of the researchers, as his institute's are, or on the details of proposals. "Do you fund people, or projects?" he asked.

Several of the 150 audience members voiced concerns about decisions that have already been made. Nicole Dicks, finance chief of California's Burnham Institute in La Jolla, says she is bothered by fine print that might make life hard for small institutes like hers. Normally, at least onethird of a grant goes to funding facilities and administration costs, but Proposition 71 caps overheads at $25 \%$. Unless this changes, only organizations big enough to pay the difference will be able to accept Proposition 71 money, she says.

Robert Klein, the Palo Alto real-estate developer who was the prime mover behind the initiative and is a likely candidate to chair the supervisory committee, remains undaunted. "These aren't pitfalls, they are challenges," he told delegates.

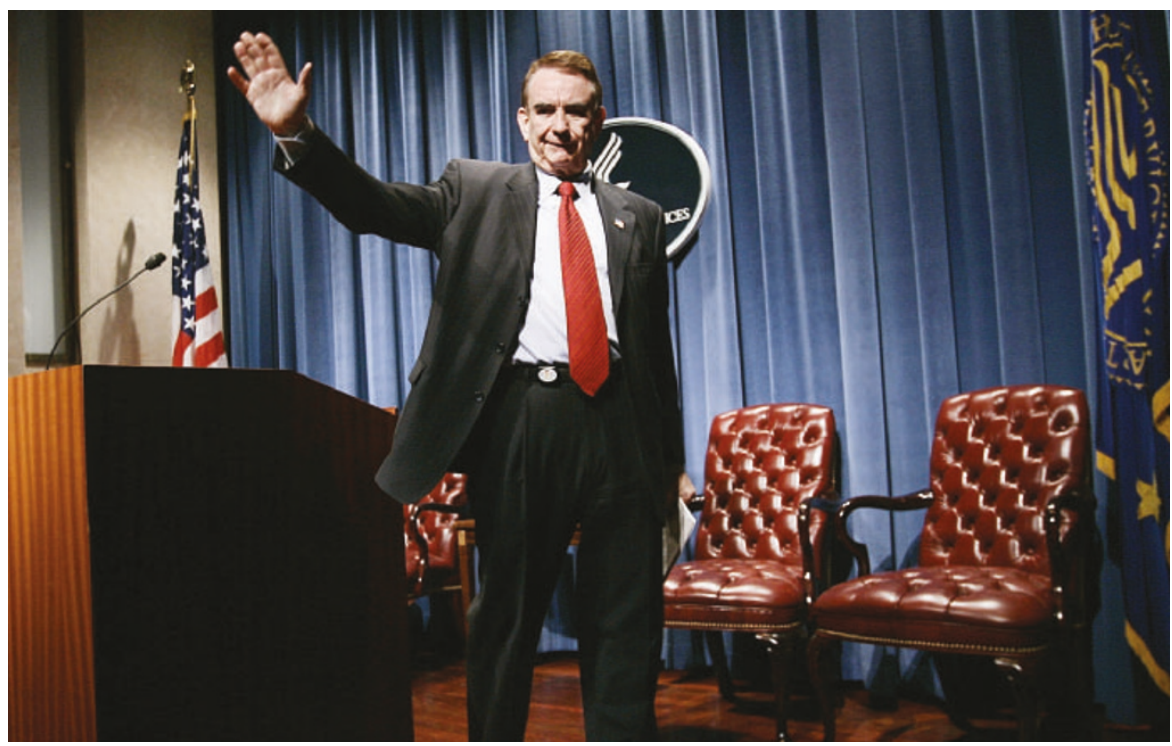

Hand over: some disgruntled researchers are glad to see US health secretary Tommy Thompson depart.

\title{
Thompson cedes crown after stormy reign over US health
}

Erika Check, Washington

With the resignation of Tommy Thompson, who has served as US health secretary since 2001, life scientists in the United States say they hope their sometimes fraught relationship with the government will improve.

In a stormy four-year tenure, Thompson often clashed with researchers at the National Institutes of Health (NIH), the main US biomedical research agency. Although part of Thompson's Department of Health and Human Services, the NIH has traditionally enjoyed considerable autonomy from it.

On 3 December, Thompson said he would step down from his position in February, and hopes to find work in the private sector. His successor is widely expected to be Mark McClellan, a physician and former commissioner of the Food and Drug Administration, who currently runs the health department's largest public-health programmes - Medicare and Medicaid.

Under Thompson, a former governor of Wisconsin, researchers at agencies such as the NIH and the Centers for Disease Control and Prevention (CDC) often chafed at what they saw as his aggressive, political approach.

Soon after he took office, for instance, Thompson irritated scientists at the NIH and CDC by proposing restrictions on travelling to scientific meetings (see Nature 411, 983; 2001). Thompson also sought to centralize certain functions of the health department, including press and congressional relations - a move that some researchers said risked politicizing the public outreach of the research agencies (see Nature415,250; 2002).

His office further drew researchers' ire by limiting the number of health-department employees who could attend the XV International AIDS Conference, held this July in Bangkok (see Nature 430, 128;2004).

Thompson's supporters counter that his high profile helped the department take the lead on national and international issues: funding for bioterorrism research and global AIDS programmes increased dramatically during his tenure.

Judith Auerbach of the American Foundation for AIDS Research remains critical of Thompson. "We hope the next secretary can avoid instances of politics and ideology influencing public-health research policy, as has happened during this past administration," she says.

"I don't think you're going to find very many people at the NIH who are doing anything but jumping for joy" at his departure, said one senior NIH scientist and administrator, who spoke on condition of anonymity.

As Thompson departed, he defended some of the Bush administration's policies, such as the restriction of federal funds for embryonic stem-cell research. But he also offered blunt warnings about a potential flu pandemic, and the risks of a bioterrorist attack on US food supplies. He praised Elias Zerhouni, director of the NIH, for his handling of a conflict-of-interest scandal at the agency.

$\mathrm{NIH}$ researchers were upbeat about McClellan's possible nomination, pointing to his medical degree and strong administrative track record. "I'm hopeful that McClellan understands the importance of biomedical research; he seems to be someone who likes to get things done," said an NIH administrator, who also asked not to be named.

For more news and analysis go to

news@ nature.com

www.nature.com/news 